\title{
Giving Meaning to the Pandemic: What Do Brazilians Think About the New Coronavirus?
}

\author{
Cynthia de Freitas Melo ${ }^{1}$ (D) Ana Mattos Brito de Almeida ${ }^{1}$. \\ Samuel Lincoln Bezerra Lins ${ }^{2}$ (D) . Sibele Dias de Aquino ${ }^{3}$ (D) \\ Icaro Moreira Costa ${ }^{1}$ (D) . Jaiana Cristina Cândido Morais ${ }^{1}$ (D)
}

Accepted: 2 April 2021 / Published online: 25 May 2021

(c) Associação Brasileira de Psicologia 2021

\begin{abstract}
In view of the pandemic scenario caused by the new coronavirus, it is crucial to produce knowledge to understand the disease and its impacts on people's daily lives. In response to this demand, the present study aimed to identify the meanings attributed to the new coronavirus by Brazilians at the beginning of the COVID-19 pandemic. We had access to a non-probabilistic sample of 2400 Brazilians, who answered a biodemographic questionnaire, using the technique of free word association, with the induced stimulus "coronavirus," respectively interpreted through descriptive statistics using the SPSS software and textual analysis using IRaMuTeQ. The results were organized into three classes: (1) "characterization of the disease," evoking responses about the treatment, risks, prevention strategies, and expectations of cure; (2) "negative repercussions," reflecting harmful aspects of the disease on mental health, such as fear, uncertainty, and despair; and (3) "positive repercussions," revealing initiatives of solidarity, empathy, and collective care as coping strategies. Differences in evocations also arose depending on the region of the country, employment status, adherence to social isolation measures, agreement with social isolation, agreement with the current president, experience of infection, and level of stress. It was concluded that identifying the meanings that Brazilians attribute to the new coronavirus is important for the formulation of effective intervention strategies.
\end{abstract}

Keywords COVID-19 $\cdot$ Coronavirus $\cdot$ Pandemics $\cdot$ Social psychology $\cdot$ Health psychology

Cynthia de Freitas Melo

cf.melo@yahoo.com.br

1 Programa de Pós-Graduação em Psicologia. Avenida Washington Soares, University of Fortaleza, 1321, Bloco E, Sala E01, Edson Queiroz, Fortaleza, CE 60811341, Brazil

2 University of Porto, Porto, Portugal

3 Pontifícia Universidade Católica Do Rio de Janeiro, Rio de Janeiro, Brazil 


\section{Dando sentido a la pandemia: qué piensan los brasileños sobre el nuevo coronavirus?}

\section{Resumen}

En vista del escenario pandémico causado por el nuevo coronavirus, es crucial generar conocimiento para comprender la enfermedad y sus impactos en la vida diaria de las personas. En respuesta a esta demanda, el presente estudio tuvo como objetivo identificar los significados que los brasileños atribuyen al nuevo coronavirus. Contamos con una muestra no probabilística de 2.400 brasileños, que respondieron un cuestionario bioemográfico y la técnica de asociación de palabras libres, con estímulo inductor "coronavirus", respectivamente entendido a través de estadística descriptiva en el software SPSS y análisis textual en IRaMuTeQ. Los resultados se organizaron en tres clases: (1) "Caracterización de la enfermedad", que evoca contenidos sobre el tratamiento, los riesgos, las estrategias de prevención y las expectativas de curación; (2) "Repercusiones negativas", que reflejan aspectos nocivos de la enfermedad para la salud mental, como el miedo, la incertidumbre y la desesperación; y (3) "Repercusiones positivas", revelando iniciativas de solidaridad, empatía y atención colectiva como estrategias de afrontamiento. También surgieron diferencias en las evocaciones según la región del país, el empleo, el cumplimiento de las medidas de aislamiento social, el acuerdo con el aislamiento social, el acuerdo con el presidente actual, la experiencia de infección y el nivel de estrés. Se concluyó la importancia de identificar los significados que los brasileños atribuyen al nuevo coronavirus, para la formulación de estrategias de intervención efectivas.

Palabras clave covid-19, coronavirus $\cdot$ pandemias $\cdot$ psicología social $\cdot$ salud psicológica

\section{Dando significado à pandemia: o que os brasileiros pensam sobre o novo coronavírus?}

\section{Resumo}

Diante do cenário de pandemia causado pelo novo coronavírus, torna-se crucial a produção de conhecimento para compreensão sobre a doença e seus impactos no cotidiano das pessoas. Em resposta a esta demanda, o presente estudo teve como objetivo identificar os significados que brasileiros atribuem ao novo coronavírus. Contou-se com amostra não probabilística de 2.400 brasileiros, que responderam a um questionário biodemografico e a técnica de associação livre de palavras, com estímulo indutor "coronavírus", respectivamente compreendidos por meio de estatística descritiva no software SPSS e análise textual no IRaMuTeQ. Os resultados organizaram-se em três classes: (1) "Caracterização da doença", evocando conteúdos sobre o tratamento, riscos, estratégias de prevenção e expectativas de cura; (2) "Repercussões negativa", refletindo aspectos prejudiciais da doença para a saúde mental, como medo, incerteza, e desespero; e (3) "Repercussões positivas", revelando iniciativas de solidariedade, empatia e cuidado coletivo como estratégias de enfren- 
tamento. Também surgiram diferenças nas evocações em função da região do país, vínculo empregatício, adesão às medidas de isolamento social, concordância com o isolamento social, concordância com o atual presidente, experiência de infecção e nível de estresse. Concluiu-se a importância de identificar os significados que brasileiros atribuem ao novo coronavírus, para formulação de estratégias de intervenção eficazes.

Palavras-chave covid-19, coronavirus $\cdot$ pandemias $\cdot$ psicologia social $\cdot$ psicologia da saúde

Since the beginning of 2020, the world has been impacted by the emergence of the new coronavirus called severe acute respiratory syndrome coronavirus 2 (SARSCoV-2), which causes coronavirus disease 2019 (COVID-19). The first cases of the disease were registered in December 2019 in Wuhan, China, but the virus spread very quickly and in a few months it reached worldwide proportions, which is why the World Health Organization (WHO) declared a public health emergency of international importance, the organization's highest level of alert, and classified it as a pandemic on March 11, 2020 (Lana et al., 2020; Pan American Health Organization [PAHO], 2020). The figures and data are impressive: at the end of 2020, 90 million COVID-19 cases and almost 2 million deaths worldwide have been confirmed. In Brazil, the end of 2020 ends with more than 8 million cases and more than 200 thousand confirmed deaths (World Health Organization, [WHO], 2020a).

Faced with the significant expansion of the pandemic and the establishment of a global health crisis, COVID-19 is one of the most commented on and discussed topics worldwide, influencing the daily life and organization of society in different countries around the world, including Brazil. It brought a concern about the high rate of contamination and transmissibility of the disease, the tendency of some cases to worsen, the absence of previous immunity, and the lack of vaccines (which only became available after a year of pandemic) or treatments with recognized efficacy (identified after a few months). At the beginning of the pandemic, in addition to the lack of knowledge about the disease's behavior, collapses in the health care area were expected, which ranged from the absence of beds in the Intensive Care Units (ICU) to the shortage of qualified professionals and equipment. The situation worsened with the country's political and economic scenario and the enormous vulnerability of the Brazilian population, with great stratifications in living conditions and social determinants of health (Garbois et al., 2017; Oliveira et al., 2020).

Faced with this context of concerns and uncertainties, different countries, including Brazil, adopted control measures and health interventions, aiming to minimize the effects of the disease and control the spread of the pandemic. The measures include hand hygiene, respiratory etiquette, wearing masks, not sharing personal items, quarantine, social isolation and distancing, closing schools and universities, closing non-essential services and shops, banning agglomerations, and restricting travel and use of public transport. With the more extreme situation of need for social distancing, the government decreed a ban on circulation on the streets, except only 
for the purchase of food, medicines, or seeking health care; this is commonly known as a lockdown (Aquino et al., 2020; Oliveira et al., 2020).

Although all measures are necessary and fundamental for the control of the pandemic, and encouraged by the WHO, the inclusion and encouragement of these measures are not carried out uniformly in the country. This is because its implementation and results are associated with socioeconomic, cultural, and political aspects, as well as the capacities and characteristics of the health system (Aquino et al., 2020).

With so many changes in daily life, as well as uncertainties and uncontrollability about the future, communication and access to information has assumed a leading role in this context. From this information, people sought to understand what is happening and tried to assign meanings to the events, which can be in relation to the emergence, transmission, control measures, prevention, and cure of diseases (Eicher \& Bangerter, 2015; Jaspal \& Nerlich, 2020; Vala \& Castro, 2017).

There was a growth in the publicizing of scientific research, media reports in their various forms (written, virtual, television), use of applications, social media, and so on. However, quality and access to data are also linked to social, educational, and economic issues. Another important aspect to be considered concerns the origin of the information and the distinct, and often contradictory, contents of the messages transmitted, creating doubts about and/or discrediting their veracity (Gao et al., 2020).

Consequently, if on the one hand access to information enables one to prepare and reorganize when dealing with life, on the other hand its excess can be harmful to mental health. This is because the interpretation and meaning attributed to the new coronavirus and the forms of reaction to the pandemic are different, with direct repercussions on psychosocial aspects (Crepaldi et al., 2020; Gao et al., 2020). Exploratory studies are fundamental to encompass the symbolic significance that the thinking of individuals attributes to everyday events (Joffe, 2003).

It is critical for psychosocial research to understand how people attribute meanings to a better comprehension of how they act in response face of dynamic and changing social realities (Power \& Velez, 2020). According to Power and Velez (2020), meanings "refer to how individuals - as agentic members of groups, communities, societies, and nations - interpret and construct norms, ideas, and attitudes in relation to their lived experiences in their social, cultural, and political contexts" (p.325).

The consumption of high amounts of information about the contagion of the disease, death rates, economic crisis, and exhaustion of health services can feed the perception of vulnerability, uncertainty, and uncontrollability about life and the future. The restrictions imposed on the world population, with the departure from physical social networks and, above all, the change in daily routines and habitual activities, have drastically affected many aspects of the daily lives of individuals, families, and the community, causing ways of "normal life" to be suspended and changed indefinitely. These changes can trigger negative emotions and feelings, such as anguish, frustration, and insecurity (Ahorsu et al., 2020; Arpaci et al., 2020; Brooks et al., 2020; Lee, 2020; Usher et al., 2020). There is also the risk of psychological distress: insomnia, symptoms of post-traumatic stress, symptoms of depression, anxiety, 
panic, frustration, and loneliness (Horesh \& Brown, 2020; Pfefferbaum \& North, 2020; Rajkumar, 2020).

All of these factors can collaborate so that social distancing is perceived and experienced as a traumatic event and is not considered as an effective public health measure. Thus, isolation can be experienced as an imposition, resembling common experiences in other contexts, such as in the penitentiary, in which isolation is a form of punishment or censorship and will not lead to collective benefit (Chatterjee \& Chauhan, 2020; Usher et al., 2020).

On the other hand, for many, the context created by the pandemic, despite being difficult and uncertain, provided an opportunity to strengthen the feeling of collectivity and solidarity. In contrast to these negative meanings about the new coronavirus and its containment measures, positive attitudes from the population are perceived that can contribute to the creation of more positive meanings about this new scenario. Mukhtar (2020) states that reformulating the situation as an opportunity to improve mental health, mindfulness, and personal growth through personal activities can become a protective factor against the psychological impact of the coronavirus.

Thus, activities such as physical exercise, meditation, reading, and other actions that cause well-being can work as resilient strategies to deal with the emotional effects caused by the pandemic. In addition, voluntary social detachment is also associated with better compliance and having less psychological impact on individuals; however, it is necessary that it be communicated comprehensively and by trusted authorities, so that there is a greater awareness from the population about this issue (Chatterjee \& Chauhan, 2020).

Support networks are also essential for maintaining balance, whether from collective or individual actions and care. Actions of solidarity, exercises in empathy, and collective responsibility can also be present in times of crisis (WHO, 2020b). Social support is comprised of a process of reciprocity, in which everyone involved is able, through action, to give more meaning and control to their lives and learn that they need each other.

Thus, group mobilizations improve well-being, enhance the ability to deal with stress, increase the empowerment of individuals, and help to overcome moments of conflict and stress, such as the current situation (Rakopoulos, 2016; Valla, 2000). Another aspect that emerges as a support for preventing crises in situations of stress and uncertainty is spirituality and religiosity (Ager \& Ager, 2016; Bentzen, 2019; Norenzayan \& Hansen, 2006; Pargament et al., 2002; Pew, 2020; Sibley \& Bulbulia, 2012).

In view of this variability in reactions to the crisis scenario, a health care is needed that is based on the understanding of the biopsychosocial integrality of the subjects, with respect to their multiple needs. In this way, the subject must be understood beyond the disease, through the constant search for a physical, psychological, social, and spiritual well-being (Faro et al., 2020; Zwielewski et al., 2020).

From so many contexts and possibilities, studies that give voice to the Brazilian population, identifying and interpreting the meanings and perceptions attributed to the new coronavirus, are extremely relevant. They can consistently support the creation of effective intervention strategies that contribute to tackling this pandemic (Leônidas \& Melo, 2018). 
The guidelines coordinated by health and educational organizations must be based on prior knowledge, based on scientific data, from information collected from the target audience of the action-the population, so that the actions are effective and can be shared through collective, not vertical, constructions. Intervention through the knowledge of the population, that is, the appropriation and understanding of what is happening in the territory, is paramount for coping with poor health conditions. Understanding the meanings beyond the disease of the Brazilian population, while adding protective factors and other conditions of the health-disease process, also helps in the process of caring for individuals (Campos, 2009). In response to the urgent demand for knowledge production that feeds the databases of the international scientific community and helps in the decision-making about interventions and care practices, this study aimed to identify the meanings attributed to the new coronavirus by Brazilians at the beginning of the pandemic. The manuscript focuses on a current, worrying, and deeply relevant topic, in scientific, social, and public health terms.

\section{Method}

\section{Study Design}

This is a descriptive, exploratory, national survey and mixed-method study. Through the combination of different methods and data sources, the natural bias that affects studies with singular approaches can be overcome (Paranhos et al., 2016).

\section{Sample}

There was a non-probabilistic convenience sample of 2400 Brazilians. The inclusion criteria were as follows: being Brazilian, living in the country, and being over 18 years of age. People without access to the internet and/or being illiterate and without reading conditions were excluded.

From the description of the sociodemographic data, it was observed that the participants had an average age of 39.11 years $(S D=14.11)$. Most were female $(n=1864 ; 77.70 \%)$, were practicing social distancing/voluntary social isolation $(n=2028 ; 84.50 \%)$, and lived in the Northeast of the country $(n=1223 ; 51.00 \%)$. In addition, the highest percentages found in the other sociodemographic data were as follows: $36 \%$ with monthly income greater than 5000 Brazilian Reals $(n=864)$, $29.50 \%$ were self-employed/liberal professionals $(n=709)$, and $48.90 \%$ had postgraduate qualifications $(n=1174)$ (see Table 1$)$.

\section{Instruments}

Participants responded to two instruments. Initially, a biodemographic questionnaire was used, containing questions about age, sex, income, employment status, education, adherence to social isolation/distancing measures, and the 
Table 1 Sociodemographic data of sample

\begin{tabular}{|c|c|c|c|}
\hline Variable & & $f$ & $\%$ \\
\hline \multirow[t]{2}{*}{ Gender } & Male & 536 & $22.30 \%$ \\
\hline & Female & 1864 & $77.70 \%$ \\
\hline \multirow[t]{7}{*}{ Income } & No income & 280 & $11.70 \%$ \\
\hline & Up to $1000 \mathrm{BRL}$ & 154 & $6.40 \%$ \\
\hline & From 1001 to $2000 \mathrm{BRL}$ & 325 & $13.50 \%$ \\
\hline & From 2001 to $3000 \mathrm{BRL}$ & 311 & $13.00 \%$ \\
\hline & From 3001 to $4000 \mathrm{BRL}$ & 243 & $10.10 \%$ \\
\hline & From 4001 to $5000 \mathrm{BRL}$ & 223 & $9.30 \%$ \\
\hline & Over $5000 \mathrm{BRL}$ & 864 & $36.00 \%$ \\
\hline \multirow[t]{5}{*}{ Employment status } & Self-employed & 709 & $29.50 \%$ \\
\hline & Formally employed & 607 & $25.30 \%$ \\
\hline & Unemployed/student & 477 & $19.90 \%$ \\
\hline & Public employee & 393 & $16.40 \%$ \\
\hline & Retired & 214 & $8.90 \%$ \\
\hline \multirow[t]{5}{*}{ Education } & Elementary & 14 & $0.60 \%$ \\
\hline & High school & 158 & $6.60 \%$ \\
\hline & Incomplete higher education & 455 & $19.00 \%$ \\
\hline & Higher education completed & 599 & $25.00 \%$ \\
\hline & Post-graduation & 1174 & $48.90 \%$ \\
\hline \multirow[t]{2}{*}{ Level of following guidelines } & Voluntary social isolation & 2028 & $84.50 \%$ \\
\hline & No social isolation & 372 & $15.50 \%$ \\
\hline \multirow[t]{5}{*}{ Region in the country } & North & 74 & $3.10 \%$ \\
\hline & Northeast & 1223 & $51.00 \%$ \\
\hline & Midwest & 48 & $2.00 \%$ \\
\hline & Southeast & 605 & $25.20 \%$ \\
\hline & South & 450 & $18.80 \%$ \\
\hline
\end{tabular}

region of the country. Then, the Free Word Association Technique (FWAT) was applied. This is a projective technique that is organized on participants evocation responses (words or ideas), from inducing stimuli previously defined by the researcher, whether verbal (word, expression, idea, phrase, proverb), image (figure, photography), video (film, advertising), or sound (a song or a sound). From it, it is possible to identify semantic universes related to an object or social phenomenon (Coutinho \& Do Bú, 2017; Dany et al., 2015; Idoiaga et al., 2020), quickly, with less cognition process and with more spontaneous and immediate responses, through a relatively simple procedure, which is one of its attractions (Ross, 2003). For its application in the present study, participants were asked to answer the following question: "What are the first 5 words that come to your mind when you hear the word "CORONAVIRUS?" Thus, it was possible to identify the immediate meanings attributed by Brazilians to the new coronavirus in the initial period of the COVID-19 pandemic. Such content, as in any social object, is not 
static. The meanings attributed to the coronavirus can change throughout the pandemic. Therefore, studies are needed to monitor this evolution of meanings over time (Ross, 2003).

\section{Data Collection Procedures}

For data collection, a form was generated on an online platform with the aforementioned instruments and the Free and Informed Consent Form (FICF) was released over 25 days (May 8 to June 1, 2020), through social networks, newspaper reports, and digital portals. After posting, people who follow these media were able to autonomously open the questionnaire and answer it individually, self-administered and anonymously, with an average duration of $15 \mathrm{~min}$.

\section{Data Analysis Procedures}

The data were analyzed in two stages. Biodemographic data were analyzed using descriptive statistics (frequency, percentage, and measures of central tendency and dispersion) in the statistical software Statistical Package for Social Science (SPSS), version 25.

The FWAT was analyzed with the aid of the software Interface de $R$ pour les Analyzes Multidimensionnelles de Textes et de Questionnaires (IRaMuTeQ), a free program, developed by the French researcher Pierre Ratinaud, which seeks to capture the structure and organization of the statements, thus being able to inform the relationships between the lexical worlds that are most often used by the research participants (Camargo \& Justo, 2013).

Four textual analyzes were carried out using the following: (1) word cloud, in order to group the words and organize them graphically according to their relevance, the largest being those that had a higher frequency, considering words with a frequency equal to or greater than 10; (2) classic lexicographic analyses to verify statistics on the number of text segments (TS), evocations, and forms; (3) descending hierarchical classification (DHC) for the recognition of the dendrogram with the classes that emerged, with the higher the $\chi^{2}$, the more associated the word is with the class, while words with $\chi^{2}<3.80(p<0.05)$ were not considered; and (4) correspondence factor analysis (CFA), to verify the differences in evocations (considering the frequency of word incidence and their hypergeometric indices $/ \chi^{2}$ ) between participants from different groups, depending on the region of the country (North, Northeast, Midwest, Southeast, and South), employment status (retired, unemployed/student or actively employed), adherence to social isolation/distancing measures (they have never been in isolation, they have been and are no longer, or currently are), agreement with the social isolation (agree or disagree), agreement with the current president's stance (agree or disagree), experience of infection (they have had COVID-19 or have never had it), and stress level (absent, mild, or high). 
Fig. 1 Word cloud

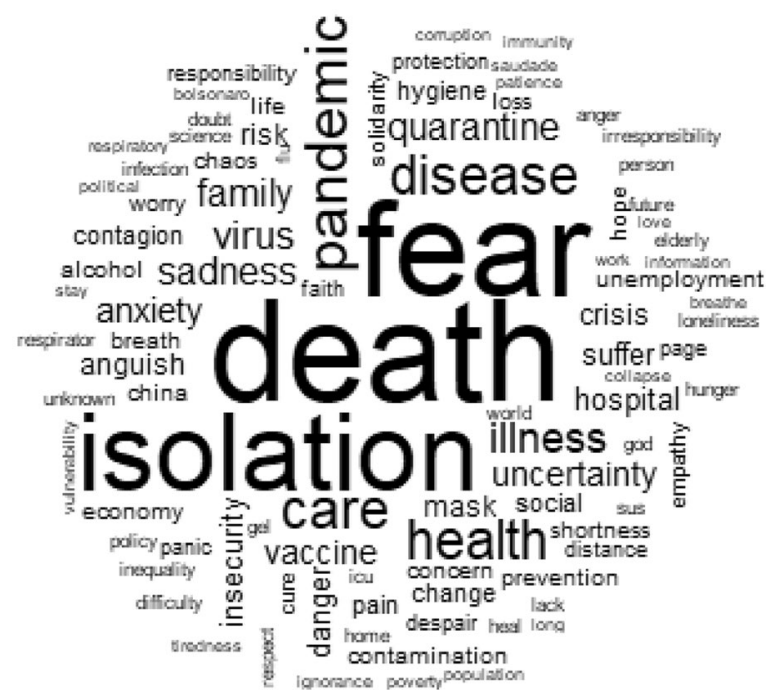

\section{Ethical Procedures}

This study was initially approved by the Research Ethics Committee, under reference No. 4,014,996, and the ethical aspects required by Resolution No. 466/12 of the National Health Council were respected.

\section{Results}

\section{Word Cloud}

First, the word cloud generated from the participants' evocations was obtained, verifying that the most representative words were as follows: "Death" $(f=972)$, "Fear" $(f=895)$; "Isolation" $(f=724)$; "Disease" $(f=482)$; "Pandemic" $(f=354)$; "Care" ( $f=322)$, "Health" $(f=258)$, and "Sadness" $(f=188)$ (see Fig. 1).

\section{Classical Lexicographic Analysis and Descending Hierarchical Classification}

In order to extract the meanings attributed by Brazilians to the new coronavirus, a corpus consisting of 2400 text segments (TS) was generated, with the use of 1899 TSs (79.09\%). A total of 13,742 occurrences (words, forms, or vocabulary) emerged, with 1675 distinct words and 884 with a single occurrence. The analyzed content was categorized into three classes and named after the evocations that emerged: Class 1-characterization of the disease, with 939 TSs (49.45\%); 


\begin{tabular}{|c|c|c|c|c|c|c|c|c|}
\hline & & \multicolumn{5}{|c|}{$\begin{array}{l}\text { Corpus of text on the meanings of the new coronavirus for Brazilians } \\
\qquad 1,899 \mathrm{TS} \text { - Use of } 79.09 \% \%\end{array}$} & & \\
\hline \multicolumn{3}{|c|}{ Class 1} & \multicolumn{3}{|c|}{ Class 2} & \multirow{2}{*}{\multicolumn{3}{|c|}{$\begin{array}{c}\text { Class } 3 \\
\text { Positive repercussions } \\
14.06 \%-267 \text { ST }\end{array}$}} \\
\hline \multicolumn{3}{|c|}{$\begin{array}{l}\text { Characterization of illness } \\
49.45 \%-939 \text { TS }\end{array}$} & \multicolumn{3}{|c|}{$\begin{array}{l}\text { Negative repercussions } \\
36.49 \%-693 \mathrm{ST}\end{array}$} & & & \\
\hline Word & $f$ & $\chi^{2}$ & Word & $f$ & $\chi^{2}$ & Word & $f$ & $\chi^{2}$ \\
\hline Pandemic & 73 & 102.66 & Fear & 451 & 264.80 & Solidarity & 52 & 24746 \\
\hline Disease & 34 & 82.64 & Uncertainty & 123 & 174.96 & Love & 22 & 136.05 \\
\hline Death & 41 & 77.87 & Sadness & 146 & 163.75 & Respect & 22 & 114.62 \\
\hline Isolation & 25 & 62.55 & Insecurity & 103 & 158.03 & Family & 30 & 105.57 \\
\hline Quarantine & 31 & 63.42 & Anxiety & 113 & 122.93 & Responsibility & 19 & 90.54 \\
\hline Virus & 62 & 57.11 & Despair & 46 & 65.22 & God & 26 & 87.75 \\
\hline Hospital & 21 & 54.26 & Change & & 52.53 & Pass & 14 & 66.33 \\
\hline Risk & 17 & 43.03 & Worry & & 49.02 & Life & 30 & 60.73 \\
\hline Contagion & 15 & 37.43 & Anger & 27 & 44.05 & Work & 15 & 57.84 \\
\hline Vaccine & 12 & 29.08 & Anguish & 49 & 42.04 & Close & 09 & 55.27 \\
\hline Mask & 42 & 40.94 & Doubt & 25 & 40.49 & Child & 12 & 54.41 \\
\hline Crisis & 82 & 33.53 & Tiredness & 21 & 36.95 & Friend & 10 & 54.08 \\
\hline ICU & 31 & 32.22 & Panic & 32 & 27.31 & Protect & 08 & 49.11 \\
\hline Danger & 64 & 20.01 & Impotence & 14 & 24.54 & Worry & 08 & 49.11 \\
\hline Bolsonaro & 21 & 18.85 & Revolt & 08 & 13.98 & Faith & 20 & 27.45 \\
\hline Flu & 20 & 17.81 & Hopelessness & 07 & 12.23 & Care & 50 & 26.69 \\
\hline
\end{tabular}

Fig. 2 Dendrograma com a distribuição das classes e suas palavras de destaque. Dendrogram with classes' distribution and their highlighted words

Class 2-negative repercussions, with 693 TSs (36.49\%); and Class 3-positive repercussions, with 267 TSs (14.06\%) (see Fig. 2).

For a better visualization of the classes, a dendrogram was created with the list of words for each class generated from the chi-squared test $\left(\chi^{2}\right)$. It showed evocations that presented vocabulary similar to each other and vocabulary different from other classes (see Fig. 2). Subsequently, the classes that emerged are described, operationalized, and exemplified in the descending hierarchical classification.

Class 1-characterization of the disease: comprises $49.45 \%$ ( $f=939$ TS) of the total analyzed corpus. It consists of words and radicals in the range between $\chi^{2}=4.10$ (apocalypse) and $\chi^{2}=102.66$ (pandemic). This class is composed of words like "Pandemic" $\left(\chi^{2}=102.66\right)$; "Disease" $\left(\chi^{2}=82.64\right)$; "Death" $\left(\chi^{2}=77.87\right)$; "Isolation" $\left(\chi^{2}=62.55\right)$; "Quarantine" $\left(\chi^{2}=63.42\right)$; "Virus" $\left(\chi^{2}=57.11\right)$; and "Hospital" $\left(\chi^{2}=54.26\right)$.

Class 2-negative repercussions: comprises $36.49 \%(f=693$ ST) of the total analyzed corpus. It consists of words and radicals in the range between $\chi^{2}=3.91$ (protection) and $\chi^{2}=264.80$ (fear). This class is composed of words like "Fear" $\left(\chi^{2}=264.80\right)$; "Uncertainty" $\left(\chi^{2}=174.96\right)$; "Sadness" $\left(\chi^{2}=163.75\right)$; "Insecurity" $\left(\chi^{2}=158.03\right)$; "Anxiety" $\left(\chi^{2}=122.93\right)$; "Despair" $\left(\chi^{2}=65.22\right)$; and "Change" $\left(\chi^{2}=52.53\right)$.

Class 3-positive repercussions: comprises $14.06 \%(f=267$ ST) of the total analyzed corpus. It consists of words and radicals in the interval between $\chi^{2}=4.28$ (pause/reinvention/security) and $\chi^{2}=247.46$ (solidarity). This class is composed of words like "Solidarity" $\left(\chi^{2}=247.46\right)$; "Love" $\left(\chi^{2}=136.05\right)$; "Respect" $\left(\chi^{2}=114.62\right)$; 
"Family" $\left(\chi^{2}=105.57\right)$; "Responsibility" $\left(\chi^{2}=90.54\right)$; "God" $\left(\chi^{2}=87.75\right)$; and "Pass" $\left(\chi^{2}=66.33\right)$.

\section{Correspondence Factor Analysis}

From the correspondence factor analysis (CFA), it was possible to make comparisons of evocations (considering the frequency of word incidence and their hypergeometric indices $/ \chi^{2}$ ) between different sociodemographic variables-region of the country, employment status, adherence to social isolation/distancing measures, agreement with social isolation, agreement with the stance of the current president, experience of infection, and level of stress.

The evocations of participants from the Midwest region focus on aspects related to the uncertainty and carelessness of government officials with the pandemic (e.g., "doubt," "neglect," "economy," "lack," and "responsibility"). Evocations in the Northeast include the risks to health and life, and the use of spirituality as a coping strategy (e.g., "symptom," "death," "infected," "disease," and "faith"). Evocations in the North are related to concerns about the exhaustion of the health system (e.g., "system," "danger," "new," "collective," and "suffering"). In the evocations of the South region, factors related to the risk of the pandemic to the economy can be found (e.g., "economy," "information," "risk," "crisis," and "exaggeration"). Finally, evocations in the Southeast region focus on the needs of hygiene care (e.g., "hygiene," "infection," and "virus").

The contents evoked by retirees focus on aspects related to suffering and the hope for a cure (e.g., "cure," "suffering," "unknown," "hope," and "poverty"). The unemployed/students contemplate the disease, its risks, and measures to control the pandemic (e.g., "disease," "quarantine," "virus," "infection," and "crisis"). People who work focus on the work-related changes and doubts that arise with the pandemic (e.g., "change," "work," "fear," and "doubt").

The responses of the subjects who have never practiced social isolation/distancing focus on aspects related to the concern with the economy and politics (e.g., "corruption," "economy," "flu," "unemployment," "work," and "politics"). The responses evoked from those who have been and are no longer practicing social isolation/distancing are related to the disbelief about the seriousness of the disease (e.g., "exaggeration," "politics," "money," "catastrophe," and "manipulation"). Finally, the responses of those who are practicing social isolation/distancing focus on the risk of the disease, the need for isolation, and expectations about science (e.g., "danger," "isolation," "science," "infection," and "virus").

The evocations of the participants who do not agree with the WHO guidelines for social isolation focus on aspects related to discrediting the seriousness of the disease and their belief in political manipulation (e.g., "corruption," "China," "politics," "exaggeration," " manipulation," and "unemployment"). People who do agree with the WHO's social isolation guidelines consider the risk of illness, need for isolation, and uncertainties about the future (e.g., "fear," "death," "isolation," "uncertainty," and "anxiety"). 
The contents evoked by the respondents who do not agree with the position of the current president focus on aspects related to the risk of the disease, the need for isolation, and the uncertainties about the future (e.g., "fear," "death," "isolation," "uncertainty," and "science"). Those who agree with the position of the current president consider disbelief about the seriousness of the disease and belief in political manipulation (e.g., "corruption," "China," "politics," "exaggeration," "manipulation," and "flu").

The responses of participants who have never been infected with COVID-19 focus on aspects related to prevention (e.g., "care," "contagion," "sanitizer," "science," and "vaccine"). Those who had been infected with COVID-19, on the other hand, focus on the experience of overcoming, reflection on the future, and mourning for those who have been lost (e.g., "symptom," "reflection," "overcoming," "future," and "mourning").

Finally, the evocations of people with no stress focus on aspects related to the hope for an end to the pandemic and opportunities that arise from this (e.g., "politicking," "faith," "home," "vaccine," and "opportunity"). People with low levels of stress consider the need for care, risk of infection, and concern about the exhaustion of the health system (e.g., "hospital," "care," "contagion," "infection," and "system"). People with a high level of stress have negative reactions to the pandemic (e.g., "despair," “distress," "anxiety," "chaos," and “depression”).

\section{Discussion}

The aim of this study was to identify the meanings that Brazilians attribute to the new coronavirus. It is important to highlight that the results follow the evolution of the virus, since from the beginning of the pandemic, little has been said about the use of masks or prevention strategies. While this study was being carried out, the information was still constantly changing, and until approval of this article, it will probably be out of date yet. However, this study stops with the analysis of the collection period, even though the pandemic continued to advance in Brazil and in the world, and the risk of chaos has not been overcome. Thus, it is important to note that this discussion lasted the period of May 8 to June 1, 2020, when Brazil recorded498,440 confirmed cases with 27,878 deaths ${ }^{1}$ Thus, the role of access to correct and up-to-date information on the progress of the pandemic should be highlighted. However, while information is important, on the other hand, excessive exposure to information during the pandemic can also be harmful (infodemic), and has been associated with mental disorders such as depression and anxiety (Gao et al., 2020). Not by chance, one of the recommendations of the World Health Organization (WHO) for tackling the new coronavirus is to minimize the attention devoted to news about COVID-19. Considering this panorama,

\footnotetext{
1 In Brazil, from Jan. 3, 2020, to 7:21 p.m. CET, 14 January 2021, there have been 8,195,637 confirmed cases of COVID-19 with 204,690 deaths. https://covid19.who.int/region/amro/country/br
} 
the relevance of the findings of the present study goes beyond the current context and the results are consistent, as described below (WHO, 2020b).

Initially, through word cloud analysis, it was found that the strongest associations with the new coronavirus are the negative words (death, fear, isolation, disease, and pandemic). This is probably due to the large number of daily deaths that are reported, even in a context of lack of testing and under-reporting. Throughout the data collection, the contagion and death curve continued to grow exponentially throughout Brazil, and negative associations attest to fear, uncertainty, the inability to control infection, and the fear of not being adequately protected (Crepaldi et al., 2020).

The major method used in this research (FWAT) accesses the latent dimensions that structure the semantic universe of the object under study. This allows the data found from the free expression of individuals to be processed directly, with rapid analysis and relative ease of understanding (Abric 2005). This method considers that the highlighted words are similar to a reflexive revision of the meaning made by the participants, who conceptually define the proposed object (Rosa \& Kirchler, 2001).

In the descending hierarchical classification, three classes emerged. The first and largest class concerns the characterization of the virus in a descriptive and objective way, evoking words such as pandemic, disease, death, and risk of contagion. In this class, terms emerged about prevention strategies ("isolation," "quarantine," and "wearing a mask"), about treatment of the disease ("ICU," "hospital"), and about the expectation of cure through a vaccine. It can be seen that this class describes the COVID-19 pandemic in its aspects related to the measures created to contain the disease and the imminent dangers that have arisen (the risk of contagion and death). Obviously, the fact that the class "characterization of the disease" is the largest confirms the role of the media and social networks in the population, who would not have access to so much descriptive, explanatory, detailed, and concrete information without a media that is active and influential.

When new events undermine individuals' worldviews, they tend to interpret and create meaning for events, and it is common for this to happen during catastrophes and with the emergence of new diseases (Vala \& Castro, 2017). Thus, as a care and protection strategy in the face of the threat, it is expected that people will tend to develop their own symbolic representations about how the disease originated, how it is transmitted, and the forms of prevention and cure (Eicher \& Bangerter, 2015).

In fact, when facing the perception of the current pandemic, of the extreme fragility of the Brazilian health system, of the imminent risk of illness or death, individuals find themselves within a context of great vulnerability, from which several emotional reactions arise. In this sense, the other two classes showed negative (Class 2) and positive (Class 3 ) repercussions caused by the new coronavirus.

The second class is related to the negative repercussions of the COVID-19 pandemic, mainly in regard to aspects harmful to mental health, such as fear, uncertainty, sadness, and despair. It cannot be dismissed that experiencing a borderline state of public health emergency triggers intensely negative emotional reactions, both in those who were infected with the new coronavirus and in those who were not, as the damage affects everyone. 
Such evocations demonstrate the extreme fragility of the country's health context, highlighting social vulnerabilities that already existed: insecurity; fear of death for the most physically compromised and fragile; and uncertainty and doubts about the future, among others. These social factors compromise the integral health of the subject, who, in addition to the absence of disease, needs physical, psychological, social, and spiritual well-being (Faro et al., 2020; Zwielewski et al., 2020).

Negative feelings, emotions, and reactions such as sadness, anxiety, impotence, revolt, and hopelessness are aroused. For this reason, scales have been developed to assess the relationship of the new coronavirus with these negative feelings, for example, the "COVID-19 Phobia Scale" (Arpaci et al., 2020), the "The Fear of COVID-19 Scale" (Ahorsu et al., 2020), and the "Coronavirus Anxiety Scale" (Lee, 2020). In addition, several studies are being carried out with the intention to understand the impacts of the pandemic on mental health, analyzing stress, depression, panic, or any psychological symptoms that affect different dimensions of life (Gao et al., 2020; Horesh \& Brown, 2020; Pfefferbaum \& North, 2020; Rajkumar, 2020; WHO, 2020b).

What is more, a third class was found that is related to the positive repercussions of COVID-19. Even while experiencing immense tension and crisis, during the pandemic, several solidarity and empathetic initiatives have been observed (e.g., helping people from risk groups to shop, displaying a rainbow icon in the window, applauding health professionals). These initiatives have a strong social appeal in the sense of reorganizing priorities as a way of valuing what really matters, highlighting the collective sense of unity. The solidarity actions displayed both individually and collectively (such as sharing resources, information, distribution of palliatives, and donations) help people to deal with the impact of COVID-19 on family livelihoods.

In this sense, this third class shows coping strategies that people use to deal with the pandemic. The strengthening of support networks, both in collective and individual care and in all group mobilizations, improves well-being, and helps to overcome the difficult moment with a collective experience, lived in a group, even though the subjects are physically isolated. In many places, neighborhood initiatives are a response to the crisis to offer help to those most in need, such as people who belong to high-risk groups who should stay at home. Igwe et al. (2020) tested the relationship between altruism, reciprocity, and solidarity during the pandemic, and found that solidarity also represents a set of beliefs, values, and even social norms that they believe would have implications for the process of community building, increasing social development and even raising the health policy agenda during disasters, emergencies, and pandemics.

It is not for nothing that "Solidarity" is the most frequently used word in the third class, and the one most strongly related to positive repercussions. Solidarity has marked several moments during the COVID-19 pandemic, driving people to somehow recover the agency in their lives, encouraging each other, and establishing or solidifying their social bonds (Rakopoulos, 2016). It is common for people to improvise meetings, debates, adapting their previous practices to maintain a routine of apparent normality within the context of social distancing.

As contradictory as it may seem, physical detachment seems to boost the connection and bond between human beings. Sending messages via applications, 
interacting on social networks, or even increasing the number of phone calls show that people are using old and new ways to maintain their relationships and sustain solidarity. At this time, worldwide public health requires both physical distance and a dense support network. Empathy and collective responsibility make up the social support that provides the basis for other strategies to deal with the pandemic, with cooperation as a fundamental weapon, exactly as practiced and recommended by the WHO (WHO, 2020b).

In addition, it is highlighted that religiosity is evoked in certain terms from the third class. Spirituality and religiosity are commonly accessed as a restraining strategy in times of crisis (Ager \& Ager, 2016; Bentzen, 2019; Norenzayan \& Hansen, 2006; Pargament et al. 2002; Sibley \& Bulbulia, 2012), and this is a strong characteristic of Brazilian society, which uses religion to deal with daily adversities and to seek relief and comfort. It can be stated that religious coping has been a coping strategy before COVID-19 (Pew, 2020).

The content of this third class portrayed strategies for survival and coping. It considers solidarity and respect for others, the care of oneself and others, and the protection of family and friends. Culturally, in less individualized and more collectivist societies, social detachment can be an even more disturbing challenge, as people often turn to one another when times get tough. Thus, a country with Brazil's social and economic challenges tends to feel and face the pandemic by compensating for the poor financial and structural conditions of the population with its interpersonal relationships. The responsibilities shared in people's social and cultural contexts provide greater social proximity, even though there is physical distance. In addition to the support network, faith and spirituality were mentioned as important coping strategies. Everything seems to be fundamental in overcoming this crisis.

Finally, correspondence factor analyses revealed that there are several factors that influence people's perception of the new coronavirus. Differences in sociodemographic characteristics (region where the subject lives and professional activity), practices and habits (level of adherence to social isolation), attitudes (agreement with WHO recommendations or with the position of the president of the republic), health experiences (having contracted the virus), and emotional aspects (stress) resulted in different meanings given to the new coronavirus.

Correspondence factor analyses reveal some dissonances between the regions of the country, associated with the characteristics of the region or the particularities that the residents experience: the Midwest, where the country's political headquarters is located, focuses on the government's position; the Northeast, the poorest region and with strong religiosity, portrays the risk to health and spirituality; the North, the region with the greatest exhaustion of health services, focuses on its concern for the system; the South, where the country's largest economic hub is located, highlights the risk to the economy from the pandemic; and the Southeast, a region concerned with care in hygiene. Such distinctions show the differences in social determinants of health in a country with continental proportions (Garbois et al., 2017; Oliveira et al., 2020).

It was also found that participants who do not agree with the WHO's guidance on social isolation have never been in isolation and are in favor of the current president of the country and are focused on aspects related to discrediting the seriousness 
of the disease and their belief in political manipulation. People who agree with the WHO's social isolation guidelines, are against the current president and are in isolation and consider the risk of the disease, the need for isolation, and the uncertainties about the future. Hence, there is an associative tendency between the attitude towards the WHO guidelines and the highlighted perceptions about the coronavirus. These results corroborate studies that have showed that factors such as media confidence, internal motivation for isolation, and beliefs in conspiracy theories are potentially important in understanding adherence to the safety guidelines regarding contagion (Bierwiaczonek et al., 2020; Kowalski et al., 2020). This portrays a political bias about a public health problem, the need to care for the quality of information passed on to the population (Gao et al., 2020), and how voluntary social detachment occurs through communication from trusted authorities (Chatterjee \& Chauhan, 2020).

\section{Final Considerations}

Despite the COVID-19 is an emerging, rapidly evolving situation, from the present study, it was possible to identify the meanings that Brazilians attribute to the new coronavirus during the first months of the pandemic. To summarize, it was identified that the Brazilian population has been informed about the disease and about the guidelines for pandemic control, signaling the role of social networks and the media in passing on information about this new reality. With the breakdown of the supposed world, and the re-elaboration on this new reality, different emotional reactions arise. The consequences of the perception of vulnerability on mental health are highlighted, generating insecurity, fear, uncertainty, and doubts. However, positive repercussions arise, such as empathy, solidarity, a sense of collectivity and mutual care, and a new meaning in life and values.

Like all scientific research, although the results obtained are theoretically consistent and represent a significant contribution to the current pandemic context, the present research has limitations. One of these refers to the sample and its characteristics, because the non-probabilistic sample, which is primarily Northeastern, female, highly educated with a high income, cannot be considered as representative of the Brazilian population. Any non-probabilistic sampling would urge caution in interpreting the results, because this can generate bias in the results extracted, since the pandemic has affected the entire country and the different Brazilian social strata. It is reiterated, however, it should be considered that it is not the purpose of this study to generalize the results, but rather to explore this reality.

Another limitation refers to the online collection structure, which may have offered limited access for participants without access to the internet or with limited reading abilities. This was, however, a methodological decision based on cost-benefit, since the online collection method allowed us to reach sample groups from different regions of a country of continental size; thus this can also be considered a positive differential of the present study.

The need for further studies addressing this theme can only be reinforced. It is suggested that this study is replicated, using the same methodology, to see how 
perceptions can change over time, especially in the period after the pandemic. It is also recommended to carry out research surveys with more representative samples of the Brazilian population and to perform a research with a longitudinal design, to assess the meanings during and after the pandemic.

The realization of a study with this theme contributes to the international scientific literature by revealing the meanings that Brazilians attribute to the new coronavirus, which can influence their behaviors related to the pandemic and to experiences of collective crises. From these data, assistance is offered to government officials to formulate more effective intervention strategies, offering quality information to the population, with correct guidelines on the disease and its prevention strategies; these risk prevention actions can be formulated and mental health can be promoted.

Supplementary Information The online version contains supplementary material available at https://doi. org/10.1007/s43076-021-00078-y.

Funding Fundação Edson Queiroz.

\section{References}

Abric, J. (2005). La recherche du noyau central et de la zone muette des représentations sociales. Dans : Jean-Claude Abric éd., Méthodes d'étude des représentations sociales (pp. 59-80). Toulouse, France: ERES. https://doi.org/10.3917/eres.abric.2003.01.0059

Ager, A., \& Ager, J. (2016). Sustainable development and religion: Accommodating diversity in a postsecular age. The Review of Faith \& International Affairs, 14(3), 101-105. https://doi.org/10.1080/ 15570274.2016.1215813

Ahorsu, D. K., Lin, C. Y., Imani, V., Saffari, M., Griffiths, M. D., \& Pakpour, A. H. (2020). The Fear of COVID-19 Scale: Development and initial validation. International Journal of Mental Health and Addiction, 1-9. https://doi.org/10.1007/s11469-020-00270-8

Aquino, E. M. L., Silveira, I. H., Pescarini, J. M., Aquino, R., \& Souza-Filho, J. A. (2020). Medidas de distanciamento social no controle da pandemia de COVID-19: Potenciais impactos e desafios no Brasil. Ciência \& Saúde Coletiva, 25(Supl. 1), 2423-2446. https://doi.org/10.1590/1413-81232 020256.1.10502020

Arpaci, I., Karataş, K., \& Baloğlu, M. (2020). The development and initial tests for the psychometric properties of the COVID-19 Phobia Scale (C19P-S). Personality and Individual Differences, 164(110108), 1-6. https://doi.org/10.1016/j.paid.2020.110108

Bentzen, J. S. (2019). Acts of God? Religiosity and natural disasters across subnational world districts. The Economic Journal, 129(622), 2295-2321. https://doi.org/10.1093/ej/uez008

Bierwiaczonek, K., Kunst, J. R., \& Pich, O. (2020). Belief in COVID-19 conspiracy theories reduces social distancing over time. Applied Psychology Health and Well-Being, 12(4), 1270-1285. https:// doi.org/10.1111/aphw.12223

Brooks, S. K., Webster, R. K., Smith, L. E., Woodland, L., Wessely, S., Greenberg, N., \& Rubin, G. J. (2020). The psychological impact of quarantine and how to reduce it: Rapid review of the evidence. The Lancet, 395(10227), 912-920. https://doi.org/10.1016/s0140-6736(20)30460-8

Camargo, B. V., \& Justo, A. M. (2013). IRAMUTEQ: Um software gratuito para análise de dados textuais. Temas em Psicologia, 21(2), 513-518. https://doi.org/10.9788/TP2013.2-16

Campos, G. W. S. (2009). Saúde, Sociedade e o SUS: O imperativo do sujeito. Saúde e Sociedade, 18(Suppl. 2), 24-34. https://doi.org/10.1590/S0104-12902009000600004

Chatterjee, K., \& Chauhan, V. S. (2020). Epidemics, quarantine and mental health. Medical Journal Armed Forces India, 76(2), 125-127. https://doi.org/10.1016/j.mjafi.2020.03.017

Coutinho, M. P. L., \& Do Bú, E. (2017). A técnica de associação livre de palavras sobre o prisma do Software tri-deuxmots (version 5.2). Revista Campo do Saber, 3(1), 219-242. Recuperado de http:// periodicos.iesp.edu.br/index.php/campodosaber/article/view/72/58 
Crepaldi, M. A., Schmidt, B., Noal, D. S., Bolze, S. D. A., \& Gabarra, L. M. (2020). Terminalidade, morte e luto na pandemia de COVID-19: Demandas psicológicas emergentes e implicações práticas. Estudos de Psicologia (Campinas), 37, e200090. https://doi.org/10.1590/1982-0275202037e200090

Dany, L., Urdapilleta, I., \& Lo Monaco, G. (2015). Free associations and social representations: Some reflections on rank-frequency and importance-frequency methods. Quality \& Quantity, 49(2), 489507. https://doi.org/10.1007/s11135-014-0005-z

Eicher, V., \& Bangerter, A. (2015). Social representations of infectious diseases. In G. Sammut, E. Andreouli, \& G. Gaskell (Eds.), Handbook of social representations (pp. 385-396). Cambridge: Cambridge University Press.

Faro, A., Bahiano, M., Nakano, T., Reis, C., Silva, B. F. P., \& Vitti, L. (2020). COVID-19 e saúde mental: A emergência do cuidado. Estudos de Psicologia (Campinas), 37, e200074. https://doi.org/10.1590/ $1982-0275202037 \mathrm{e} 200074$

Gao, J., Zheng, P., Jia, Y., Chen, H., Mao, Y., Chen, S., ..., \& Dai, J. (2020). Mental health problems and social media exposure during COVID-19 outbreak. Plos one, 15(4), e0231924. https://doi.org/10. 1371/journal.pone.0231924

Garbois, J. A., Sodré, F., \& Dalbello-Araujo, M. (2017). Da noção de determinação social à de determinantes sociais da saúde. Saúde em Debate, 41(112), 63-76. https://doi.org/10.1590/0103-11042 01711206

Horesh, D., \& Brown, A. D. (2020). Traumatic stress in the age of COVID-19: A call to close critical gaps and adapt to new realities. Psychological Trauma: Theory, Research, Practice, and Policy, 12(4), 331-335. https://doi.org/10.1037/tra0000592

Idoiaga, N., Berasategi, N., Eiguren, A., \& Picaza, M. (2020). Exploring children's social and emotional representations of the COVID-19 pandemic. Frontiers in Psychology, 11, 1952. https://doi.org/10. 3389/fpsyg.2020.01952

Igwe, P. A., Ochinanwata, C., Ochinanwata, N., Adeyeye, J. O., Ikpor, I. M., Nwakpu, S. E., ... \& Umemezia, E. I. (2020). Solidarity and social behaviour: How did this help communities to manage COVID-19 pandemic?. International Journal of Sociology and Social Policy. https://doi.org/10. 1108/IJSSP-07-2020-0276

Jaspal, R., \& Nerlich, B. (2020). Social representations, identity threat and coping amid COVID-19. Psychological Trauma: Theory, Research, Practice, and Policy. 1-5. https://doi.org/10.1037/tra0000773

Joffe, H. (2003). Risk: From perception to social representation. British Journal of Social Psychology, 42(1), 55-73

Kowalski, J., Marchlewska, M., Molenda, Z., Górska, P., \& Gawęda, Ł. (2020). Adherence to safety and self-isolation guidelines, conspiracy and paranoia-like beliefs during COVID-19 pandemic in Poland - associations and moderators. Psychiatry research, 294, 113540. https://doi.org/10.1016/j. psychres.2020.113540

Lana, R. M., Coelho, F. C., Gomes, M. F. C., Cruz, O. G., Bastos, L. S., Villela, D. A. M., \& Codeço, C. T. (2020). Emergência do novo coronavírus (SARS-CoV-2) e o papel de uma vigilância nacional em saúde oportuna e efetiva. Cadernos De Saúde Pública, 36(3). https://doi.org/10.1590/0102-311x0 0019620

Leônidas, S. R., \& Melo, C. F. (2018). Avaliação do centro de referência em saúde do trabalhador cearense pelos usuários e representante dos sindicatos. Psico-USF, 23(1), 127-138. https://doi.org/10. $1590 / 1413-82712018230111$

Lee, S. (2020). Measuring coronaphobia: The psychological basis of the Coronavirus Anxiety Scale. The Journal of Psychiatry and Neurological Sciences. 33. https://doi.org/10.14744/DAJPNS.2020. 00069

Mukhtar, S. (2020). Mental health and psychosocial aspects of coronavirus outbreak in Pakistan: Psychological intervention for public mental health crisis. Asian Journal Of Psychiatry, 51, 102069. https://doi.org/10.1016/j.ajp.2020.102069

Norenzayan, A., \& Hansen, I. G. (2006). Belief in supernatural agents in the face of death. Personality and Social Psychology Bulletin, 32(2), 174-187. https://doi.org/10.1177/0146167205280251

Oliveira, W. K., Duarte, E., França, G. V. A., \& Garcia, L. P. (2020). Como o Brasil pode deter a COVID19. Epidemiologia e Serviços de Saúde, 29(2), e2020044. https://doi.org/10.5123/s1679-49742 020000200023

Pan American Health Organization .(2020). Folha informativa - COVID-19 (doença causada pelo novo coronavírus). Retrieved from: de https://www.paho.org/bra/index.php?option=com_content\&view= article\&id=6101: covid19\&Itemid $=875$ 
Paranhos, R., Figueiredo Filho, D. B., Rocha, E. C., Silva Júnior, J. A., \& Freitas, D. (2016). Uma introdução aos métodos mistos. Sociologias, 18(42), 384-411. https://doi.org/10.1590/15174522018004221

Pargament, K. I., Tarakeshwar, N., Ellison, C. G., \& Wulff, K. M. (2002). Religious coping among the religious: The relationships between religious coping and well-being in a national sample of Presbyterian clergy, elders, and members. Journal for the Scientific Study of Religion, 40(3), 497-513. https://doi.org/10.1111/0021-8294.00073.

Pew (2020a). "Few Americans say their house of worship is open, but a quarter say their faith has grown amid pandemic", Pew Research Center, Fact Tank, 30 April. Retrieved from: https://pewrsr.ch/ 3eZZw8V

Pfefferbaum, B., \& North, C. S. (2020). Mental health and the COVID-19 pandemic. New England Journal of Medicine. https://doi.org/10.1056/NEJMp2008017

Power, S. A., \& Velez, G. (2020). The MOVE framework: Meanings, observations, viewpoints, and experiences in processes of social change. Review of General Psychology, 24(4), 321-334. https://doi. org/10.1177/1089268020915841

Rajkumar, R. P. (2020). COVID-19 and mental health: A review of the existing literature. Asian Journal of Psychiatry, 52, 102066. https://doi.org/10.1016/j.ajp.2020.102066.

Rakopoulos, T. (2016). Solidarity: The egalitarian tensions of a bridge-concept. Social Anthropology, 24(2), 142-151. https://doi.org/10.1111/1469-8676.12298

Ross, T. P. (2003). The reliability of cluster and switch scores for the controlled oral word association test. Archives of Clinical Neuropsychology, 18, 153-164.

Rosa, A. S., \& Kirchler, E. (2001). Ambiguous images in advertising: An application of the associative network. Everyday Representations of the Economy, WUV-Verlag, Wien, 49-65.

Sibley, C. G., \& Bulbulia, J. (2012). Healing those who need healing: How religious practice interacts with personality to affect social belonging. Journal for The Cognitive Science of Religion, 1(1), 29-45. https://doi.org/10.1558/jcsr.v1i1.29

Usher, K., Bhullar, N., \& Jackson, D. (2020). Life in the pandemic: Social isolation and mental health. Journal Of Clinical Nursing. https://doi.org/10.1111/jocn.15290

Valla, V. V. (2000). Redes sociais, poder e saúde à luz das classes populares numa conjuntura de crise. Interface - Comunicação, Saúde, Educação, 4(7), 37-56. https://doi.org/10.1590/s1414-32832 000000200004

Vala, J., \& Castro, P. (2017). Pensamento social e representações sociais. In J. Vala \& M. B. Monteiro (Eds.), Psicologia social, (10th. (pp. 569-600). Fundação Gulbelkian.

World Health Organization. (2020a) Coronavirus disease (COVID-2019) situation reports. World Health Organization. Retrieved from: https://www.who.int/docs/default-source/coronaviruse/situationreports/20200604-covid-19-sitrep-136.pdf?sfvrsn=fd36550b_2

World Health Organization. (2020b). Mental health and psychosocial considerations during the COVID19 outbreak. World Health Organization. Retrieved from: https://apps.who.int/iris/bitstream/handle/ 10665/331490/WHO-2019-nCoV-MentalHealth-2020.1-eng.pdf

Zwielewski, G., Oltramari, G., Santos, A. R. S., Nicolazzi, E. M. S., Moura, J. A., Sant'Ana, V. L. P., Schlindwein-Zanini, R., \& Cruz, R. M. (2020). Protocolos para tratamento psicológico em pandemias: As demandas em saúde mental produzidas pela Covid-19. Revista Debates in Psychiatry - RDP, 10,2-9. Retrieved from: https://d494f813-3c95-463a898cea1519530871.filesusr.com/ugd/c37608_ 7 af7248c091241cd845b83bf82abce8a.pdf 